KOŚCIÓŁ I PRAWO 8(21) 2019, nr 2, s. 131-142

DOI: http://dx.doi.org/10.18290/kip.2019.8.2-8

\author{
Monika Górna
}

\title{
WPEYW DOCHODZENIA PRZEDPROCESOWEGO NA PRZEBIEG PROCESU O STWIERDZENIE NIEWAŻNOŚCI MAŁŻEŃSTWA
}

Papież Franciszek mając na uwadze małżonków, którzy po zawarciu małżeństwa kanonicznego zerwali wspólnotę życia i zawarli nowe małżeństwo, a pragną uregulować swój status na forum kościelnym, chce ułatwić im dostęp do instytucji i osób, które pomogłyby im w rozwiązaniu ich problemu. To właśnie temu celowi została poświęcona reforma procesu małżeńskiego z 2015 r. Pomimo wielu zmian dokonanych w procesie małżeńskim, w niniejszym artykule zostanie jedynie ukazane znaczenie dochodzenia przedprocesowego, nie tylko w kontekście odrębnej instytucji, ale również w odniesieniu do całego procesu o nieważność małżeństwa. To właśnie ze względu na znaczenie tej instytucji dla całego procesu, należy poświęcić temu zagadnieniu szczególną uwagę. Natomiast w odniesieniu do samej reformy procesu małżeńskiego trzeba zauważyć, że jest ona wynikiem obserwacji aktualnej sytuacji małżeństw i rodzin. Papież Franciszek wielokrotnie podkreśla w motu proprio Mitis Iudex Dominus Iesus ${ }^{1}$, że reforma

MGr LIC. Monika GóRnA - doktorant, Katedra Kościelnego Prawa Procesowego, Małżeńskiego i Karnego oraz Katolickich Kościołów Wschodnich, Instytut Prawa Kanonicznego, Wydział Prawa, Prawa Kanoniczego i Administracji Katolickiego Uniwersytetu Lubelskiego Jana Pawła II; adres do korespondencji: Al. Racławickie 14, 20-950 Lublin, Polska; e-mail: monikagorna94@gmail.com; https://orcid.org/00000002-8494-4417

${ }^{1}$ Franciscus PP., Litterae apostolicae motu proprio Mitis Iudex Dominus Iesus quibus canones Codicis Iuris Canonici de Causis ad Matrimonii nullitatem declarandam reformatur (15.08.2015), AAS 107 (2015), s. 958-67; tekst polski: Franciszek, List apostolski motu proprio Mitis Iudex Dominus Iesus reformujący kanony Kodeksu 
ta ma na celu przede wszystkim przyspieszenie i uproszczenie procedury stwierdzenia nieważności małżeństwa, a nie promowanie nieważności małżeństwa.

\section{POJĘCIE I CEL DOCHODZENIA PRZEDPROCESOWEGO}

Definicję prawną dochodzenia (badania) przedprocesowego zawarto w art. 2 Ratio procedendi ${ }^{2}$, wskazując miejsce, cel oraz przedmiot badania. Ponadto określając badanie przedprocesowe jako badanie duszpasterskie, ustawodawca chciał je odróżnić od dochodzenia wstępnego, które ma miejsce w procesie karnym. Zgodnie z przywołanym przepisem, dochodzenie przedprocesowe powinno mieć miejsce $\mathrm{w}$ ramach diecezjalnego duszpasterstwa małżeństw ${ }^{3}$. Jest ono skierowane do małżonków znajdujących się w separacji albo już rozwiedzionych, którzy są przekonani o nieważności swojego małżeństwa lub poddają jego ważność w wątpliwość. Badanie przedprocesowe ma na celu przede wszystkim uzyskanie informacji, które mogą być pomocne w procesie o stwierdzenie nieważności małżeństwa. Cel badania wyznacza również jego zakres przedmiotowy, który obejmuje: sytuację przed zawarciem małżeństwa, okoliczności zawarcia małżeństwa oraz sytuację, w jakiej obecnie znajdują się małżonkowie. W badaniu należy zwrócić szczególną uwagę na te informacje, które są podstawą materialną do stwierdzenia nieważności małżeństwa oraz na okoliczności umożliwiające przeprowadzenie procesu skróconego (art. $14 \quad \S \quad 1 \quad$ Ratio $^{4}$ ).

Prawa Kanonicznego dotyczące spraw o orzeczenie nieważności małżeństwa (tekst łacińsko-polski), Wydawnictwo Diecezji Tarnowskiej Biblos, Tarnów 2015 [dalej cyt.: MIDI].

${ }^{2}$ Dalej cyt.: Ratio. Zgodnie z art. 2 Ratio, „badanie przedprocesowe, czyli duszpasterskie, które odbywa się w strukturach parafialnych lub diecezjalnych dla wiernych będących w separacji lub rozwiedzionych, poddających w wątpliwość ważność ich małżeństwa lub przekonanych o jego nieważności, zmierza do zapoznania się z ich sytuacją oraz ukierunkowane jest na zebranie informacji użytecznych dla procesu sądowego, zwykłego lub skróconego. Takie dochodzenie winno mieć miejsce w ramach jednolitego diecezjalnego duszpasterstwa małżeństw”.

${ }^{3}$ Przez tę instytucję należy rozumieć duszpasterstwo odbywające się w ramach parafii oraz specjalistycznych form duszpasterza praktykowanych na poziomie parafii lub diecezji, które obejmują troską małżeństwa i rodziny [Kroczek 2015, 4].

4 „Wśród okoliczności dotyczących rzeczy lub osób, które dopuszczają rozeznanie sprawy o nieważność małżeństwa, stosując proces skrócony według kan. 1683-1687, należy zaliczyć na przykład: taki brak wiary, który może prowadzić do symulacji konsensu lub błędu determinującego wolę, krótki czas pożycia małżeńskiego, aborcję 
Natomiast nie powinno się zbierać informacji, które nie mają znaczenia dla procesu. Przez cały czas trwania dochodzenia nie wolno bezprawnie naruszać dobrego imienia oraz prawa do własnej intymności, zaś uzyskane informacje należy traktować jako informacje poufne. Nie wymaga się, aby małżonkowie lub osoby podające przedmiotowe informacje składały przysięgę [Kroczek 2015, 44].

Ustawodawca w art. 1 Ratio przypomina, iż biskup diecezjalny na mocy kan. $383 \S 1$ Kodeksu Prawa Kanonicznego z 1983 r. ${ }^{5}$ „obowiązany jest w duchu apostolskim troszczyć się o małżonków będących w separacji lub rozwiedzionych, którzy z racji uwarunkowań swojego życia porzucili być może praktyki religijne”, a także „dzieli tę troskę duszpasterską z proboszczami względem tych wiernych, którzy znajdują się w trudnej sytuacji" [Góralski 2017, 45-46]. Z tego też względu udział proboszcza w dochodzeniu jest zwyczajnym działaniem duszpasterskim, które realizuje pod przewodnictwem biskupa [Adamowicz 2015, 99]. Przedmiotem tej troski są zwłaszcza małżonkowie pozostający w separacji lub rozwiedzeni, którzy potrzebują duszpasterskiego towarzyszenia, o którym mowa w adhortacji apostolskiej Evangelii gaudium ${ }^{6}$ [Góralski 2015, 19]. Konsultacja przedprocesowa ma przede wszystkim ułatwić dostęp do procesu o nieważność małżeństwa. Papież Franciszek tłumaczy, iż wprowadzona reforma ma na celu przyspieszenie procesów oraz ich uproszczenie w taki sposób, aby wierni nie musieli zbyt długo oczekiwać na wydanie wyroku w ich sprawie (MIDI, Preambuła).

Instytucja konsultacji przedprocesowej stanowi autonomiczną i kwalifikowaną posługę asystencji przedprocesowej. Nie ma natomiast charakteru

dokonaną dla uniknięcia zrodzenia potomstwa, pozostawanie w relacji pozamałżeńskiej w czasie zawierania małżeństwa lub wkrótce po ślubie, podstępne zatajenie bezpłodności, poważnej choroby zakaźnej, potomstwa z wcześniejszego związku lub pozbawienia wolności, zawarcie małżeństwa z przyczyny całkowicie obcej życiu małżeńskiemu lub wynikające z nieoczekiwanej ciąży kobiety, użycie przemocy fizycznej w celu wymuszenia konsensu, brak używania rozumu potwierdzony dokumentacją medyczną itd.”.

${ }^{5}$ Codex Iuris Canonici auctoritate Ioannis Pauli PP. II promulgatus (25.01.1983), AAS 75 (1983), pars II, s. 1-317; tekst polski w: Kodeks Prawa Kanonicznego, przekład polski zatwierdzony przez Konferencję Episkopatu, Pallottinum, Poznań 1984 [dalej cyt.: KPK/83].

6 Franciscus PP., Adhortatio apostolica de Evangelio Nuntiando nostra aetate Evangelii gaudium (24.11.2013), AAS 105 (2013), s. 1019-137; tekst polski: Ojciec Święty Franciszek, Adhortacja apostolska Evangelii Gaudium. O głoszeniu Ewangelii w dzisiejszym świecie, Wydawnictwo „M”, Kraków 2013, nr 169. 
obligatoryjnego, a zatem nie zamyka drogi do podjęcia działań przez samą osobę zainteresowaną lub jej patrona [Góralski 2017, 46]. Ponadto we wprowadzeniu do Zasad proceduralnych ustawodawca zauważa, że ze względu na trudności wiernych w dotarciu do trybunałów kościelnych, należy przedstawiać niektóre narzędzia, dzięki którym praca trybunałów mogłaby sprostać potrzebom wiernych, którzy zwrócili się z prośbą o ustalenie prawdy o istnieniu lub nieistnieniu węzła po rozpadzie ich małżeństwa [Góralski 2017, 47].

Do najważniejszych informacji, jakie trzeba zebrać w trakcie dochodzenia przedprocesowego należy zaliczyć przede wszystkim przesłanki do przeprowadzenia postępowania o stwierdzenie nieważności małżeństwa w formie skróconej. W szczególności powinno zbadać się, czy oboje małżonkowie żądają jego przeprowadzenia, czy też jest to żądanie jednego małżonka za zgodą drugiego. Zadanie to wynika z zachęty prawodawcy, aby gdy tylko to możliwe przeprowadzać procesy w trybie skróconym [Kroczek 2015, 48].

Badanie przedprocesowe nie jest instytucją, która przynależy tylko do procesu skróconego, ale jest wskazaniem ogólnym, które ma charakteryzować reformę papieża Franciszka.

\section{CHARAKTER DOCHODZENIA PRZEDPROCESOWEGO}

Celem analizowanej instytucji realizowanym $\mathrm{w}$ drodze dochodzenia duszpasterskiego, jest zebranie tzw. danych użytecznych dla ewentualnego wszczęcia sprawy o nieważność małżeństwa we właściwym trybunale, po zaskarżeniu złożonym przez zainteresowanych małżonków albo przez ich pełnomocników i adwokatów. Na tym etapie strony mogą korzystać z pomocy pełnomocników i adwokatów osobno lub wspólnie. W badaniu przedprocesowym należy ustalić, czy strony są zgodne, co do podjęcia czynności skutecznego wniesienia skargi wszczynającej proces o nieważność małżeństwa (art. 4 Ratio). Dochodzenie powinno doprowadzić do zgromadzenia wszystkich istotnych danych, które będą wystarczające do sformułowania skargi powodowej. Powstanie skargi kończy ten etap, który będzie kontynuowany w formie procesu, o ile strony wyrażą ostateczną wolę złożenia skargi we właściwym trybunale (art. 5 Ratio). W trakcie postępowania przedprocesowego strony mogą otrzymać merytoryczną pomoc 
w zakresie przygotowania skargi powodowej. Strona (lub obie strony) inicjująca rozpoczęcie procesu może zwrócić się do swojego proboszcza, innego kapłana lub innej wyznaczonej osoby o udzielenie pomocy w zredagowaniu skargi [Wenz 2016, 242].

Pomimo, iż w art. 2 Ratio użycie zwrotu investigatio praeiudicialis seu pastoralis (dochodzenie przedprocesowe, czyli duszpasterskie), zaś w art. 4 investigatio pastoralis, może nasuwać wniosek, że sam proces małżeński nie ma charakteru duszpasterskiego, co nie odpowiadałoby prawdzie, ponieważ cała aktywność Kościoła, przez którą urzeczywistnia się zbawcza misja Chrystusa, ma charakter na wskroś duszpasterski [Góralski 2017, 48]. Badanie przedprocesowe ma charakter prawno-duszpasterski i taki też tytuł otrzymał punkt pierwszy rozdziału pierwszego Sussidio applicativo ${ }^{7}$. O takim charakterze konsultacji przedprocesowych przesądza dyspozycja wyrażona w art. 1-5 Ratio. We wstępie do rozdziału pierwszego Sussidio applicativo zamieszczono stwierdzenie, iż „skuteczna aplikacja nowego procesu o nieważność małżeństwa wymaga struktur jurydycznych oraz posługi duszpasterskiej, dzięki której wierni będą mogli zwrócić się z ewentualną prośbą o stwierdzenie nieważności małżeństwa czy to do biskupa, czy też do trybunału sąsiedniego. Postanowienia Ratio odnośnie do konsultacji przedprocesowych nie są czymś nowym w kanonicznym porządku prawnym, bowiem tę kwestię regulował art. $113 \S 1$ instrukcji Dignitas connubir ${ }^{8}$, stanowiąc że „przy każdym sądzie powinien istnieć urząd lub osoba, aby każdy mógł swobodnie i szybko uzyskać poradę dotyczącą możliwości i sposobu postępowania zmierzającego do wprowadzenia swojej sprawy o nieważność małżeństwa, jeśli istnieje ku temu podstawa” [Góralski 2017, 49].

Cel dochodzenia przedprocesowego został określony w art. 2 Ratio jako dążenie do zapoznania się z sytuacją stron oraz ukierunkowaniem na zebranie informacji użytecznych dla przyszłego procesu. Natomiast w art. 4 Ratio przyjęto, że w ramach dochodzenia zbiera się przydatne informacje dla ewentualnego wszczęcia sprawy przed właściwym trybunałem przez

7 Tribunale Apostolico della Rota Romana, Sussidio applicativo del Motu pr. "Mitis Iudex Dominus Iesus», Città del Vaticano 2016, s. 13.

${ }^{8}$ Pontificium Consilium de Legum Textibus, Instructio servanda a tribunalibus dioecesanis et interdioecesanis in pertractandis causis nullitatis matrimonii Dignitas connubii (25.01.2005), „Communicationes” 37 (2005), s. 11-92; tekst polski w: Komentarz do Instrukcji Procesowej „Dignitas connubii”, red. T. Rozkrut, Wydawnictwo Diecezjalne i Drukarnia w Sandomierzu, Sandomierz 2007 [dalej cyt.: DC]. 
małżonków lub ich adwokata. Jednocześnie należy zbadać, czy strony są zgodne między sobą co do żądania stwierdzenia nieważności, co jest szczególnie ważne w przypadku prowadzenia procesu w trybie skróconym. Po zebraniu wszystkich informacji dochodzenie kończy się sporządzeniem skargi powodowej w celu złożenia jej we właściwym trybunale [Góralski 2017, 50-51].

Przedmiotem konsultacji przedprocesowej włączonej w duszpasterstwo małżeństw i rodzin jest konkretna sytuacja małżonków rozpoznawana w różnych aspektach. Rozeznanie to może obejmować zarówno małżonków, którzy napotykają w życiu wspólnym różnorodne trudności, w rozwiązaniu których trzeba im pomóc oraz tych, którzy się rozwiedli i związali się innymi związkami, a chcą otrzymać wiedzę co do możliwości ubiegania się o stwierdzenie nieważności małżeństwa [tamże]. Badanie przedprocesowe może nie tylko wspierać małżonków w przygotowaniu procesu, ale także w przezwyciężeniu kryzysów małżeńskich. Zatem konsultacja nie powinna ograniczać się tylko do stwierdzenia stanu bezpowrotnej i definitywnej separacji stron, ale zmierzać do poznania przyczyn niepowodzenia małżeńskiego, zaś traktowanie tego rodzaju badania wyłącznie jako etapu wstępnego i narzędzia do przygotowania skargi powodowej nie byłoby właściwe. Ponadto należy mieć na uwadze, że konsultant nie jest sędzią [tamże, 52-53].

Konsultacja przedprocesowa może mieć miejsce w odniesieniu do każdej formy procesu o nieważność małżeństwa (zwyczajnego, skróconego oraz dokumentalnego), ale szczególne znaczenie może mieć w stosunku do procesu skróconego przed biskupem, które skłania małżonków do zwrócenia się o postępowanie bardziej szybkie. Dochodzenie powinno odbywać się w strukturach parafialnych, diecezjalnych lub międzydiecezjalnych, a więc na trzech poziomach. Najlepszym środowiskiem do przeprowadzenia dochodzenia jest parafia, jeśli tylko znajdzie się w niej odpowiednio wykwalifikowany personel [tamże, 57-58].

\section{PODMIOTY DOCHODZENIA PRZEDPROCESOWEGO}

W art. 3 Ratio określono, komu powinno zostać powierzone przeprowadzenie badania przedprocesowego. Ustawodawca stanowi, iż to na ordynariuszu miejsca ciąży obowiązek wyznaczenia kompetentnych osób, które upoważni do wykonania tego zadania. Ponadto ustawodawca dokonał 
podziału tychże osób na dwie grupy. Do pierwszej z nich zaliczył osoby, które mogą być upoważnione przez ordynariusza miejsca do sprawowania tego zadania przez ogólne opisanie funkcji, którą pełnili podczas przygotowania do małżeństwa. Zatem będą to głównie proboszczowie lub inni duchowni, którzy przygotowywali narzeczonych do małżeństwa, a w pewnych okolicznościach mogą to być także osoby świeckie. Do drugiej grupy należą osoby, które powinny uzyskać indywidualne zatwierdzenie ordynariusza miejsca, przy czym forma zatwierdzenia może być dowolna. Ordynariusz miejsca może swobodnie ustanowić wymagania kompetencyjne dla tych osób i dopuszczać do tego grona osoby po egzaminie lub innej formie weryfikacji kompetencji [Kroczek 2015, 46].

Przeprowadzenie dochodzenia przedprocesowego ordynariusz miejsca powinien powierzyć osobom uznanym za odpowiednie, choć ich kompetencje nie muszą być prawno-kanoniczne. Tymi osobami powinny być proboszcz albo osoba, która przygotowywała małżonków do zawarcia małżeństwa. Z dyspozycji art. 3 Ratio oraz Sussidio applicativo wynika, iż zadaniem ordynariusza miejsca jest powierzenie posługi konsultacyjnej osobom odpowiednim do takiego zadania. Osoby powołane do przeprowadzania dochodzenia powinny posiadać odpowiednie kwalifikacje (niekoniecznie w zakresie prawa kanonicznego). Nasuwa się tutaj wniosek, aby osoby te przeszły określoną formację i aby dysponowały wielostronnym przygotowaniem. Wikariusz sądowy oraz sędziowie nie powinni podejmować tejże funkcji, ani też udzielać rad lub wskazówek małżonkom zainteresowanym procesem, ponieważ byłoby to sprzeczne ze sprawowanym urzędem. Natomiast podmiotem biernym są osoby żyjące w separacji lub rozwiedzione poddające w wątpliwość ważność swojego małżeństwa lub przekonane o jego nieważności (art. 2 Ratio) [Góralski 2017, 55-57].

Czynności dochodzenia przedprocesowego powinny być realizowane dla wiernych żyjących w separacji lub rozwiedzionych, którzy mają wątpliwości co do ważności swojego małżeństwa albo są przekonani o jego nieważności. Określone formy i podjęte czynności w trakcie dochodzenia przedprocesowego muszą być skierowane na poznanie realnej sytuacji tych osób oraz na zebranie argumentów użytecznych do ewentualnego przeprowadzenia procesu. Ten rodzaj dochodzenia $\mathrm{z}$ reguły będzie odbywał się w ramach działalności diecezjalnego duszpasterstwa małżeństw i rodzin. W realizacji takiego rozwiązania właściwą pozycję zajmowaliby proboszczowie wspólnot parafialnych i inni duszpasterze, którzy otrzymali kościelne 
upoważnienie do odpowiedzialnego przygotowania nupturientów przed zawarciem małżeństwa, ponieważ posiadają wiedzę kanoniczną oraz praktykę pastoralną, z której ustawodawca chce skorzystać dla dobra wiernych i potrzeb sądu kościelnego. Na tym etapie zainteresowane strony mogą skorzystać z praktyki, wiedzy i dobrej znajomości dyscypliny kościelnej, gdy podejmują rozmowę na temat przyczyn i procedury w zakresie procesu o stwierdzenie nieważności małżeństwa. Co do zasady, sąd kościelny zwraca się do proboszcza miejsca zawarcia małżeństwa o dostarczenie protokołu z rozmowy kanoniczno-duszpasterskiej z narzeczonymi, a także o opinię na temat samych nupturientów, ich postawy w okresie narzeczeństwa, znajomości przedślubnej, a także podjętego przygotowania stron do zawarcia małżeństwa. Dochodzenie przedprocesowe może być również powierzone osobom, które zostały uznane przez biskupa diecezjalnego za zdatne do takiej posługi, a ponadto posiadają właściwe kompetencje (niekoniecznie jurydyczno-kanoniczne). Ustawodawca na pierwszym miejscu wskazał proboszcza stron i duchownego, który przygotowywał narzeczonych do zawarcia małżeństwa. Realizację zadania przeprowadzenia badania przedprocesowego można powierzyć także innym duchownym, osobom konsekrowanym a nawet świeckim, jeśli tylko zostali zatwierdzeni przez ordynariusza miejsca (art. 3 Ratio) [Wenz 2016, 239-41].

W dalszej części komentowanego przepisu została zawarta norma kompetencyjna dla ordynariusza miejsca w celu utworzenia stałej struktury, której zadaniem będzie przeprowadzenie badania przedprocesowego. Może to być pion lub komórka w istniejących strukturach duszpasterstwa małżeństw i rodzin. Ponadto istnieje możliwość, aby kilka diecezji ${ }^{9}$ połączyło wysiłki w przedmiotowym zakresie. Ustawodawca zachęca również, aby zostało przygotowane vademecum zawierające istotne wskazania do odpowiedniego przeprowadzenia dochodzenia. Vademecum może obejmować zagadnienia prawnomaterialne oraz proceduralne dotyczące przedmiotowego badania. Powinno również określać informacje, jakie należy zbierać podczas badania, mogą również znaleźć się w nim informacje z zakresu procesu małżeńskiego. Przede wszystkim powinno mieć ono charakter

\footnotetext{
${ }^{9}$ Przez diecezje należy rozumieć również inne jednostki administracyjne Kościoła zrównane w prawie diecezją, tj. prałaturę terytorialną, opactwo terytorialne, wikariat apostolski, prefekturę apostolską oraz administraturę apostolską erygowaną na stałe (kan. $368 \mathrm{KPK} / 83$ ), a także struktury personalne utworzone na podstawie kan. $372 \S 2$ $\mathrm{KPK} / 83$.
} 
praktycznego podręcznika. Zachowanie procedury z vademecum może być objęte nakazem kanonicznym, lecz niezastosowanie przepisanej $\mathrm{w}$ nim procedury nie skutkuje nieważnością zebranego $\mathrm{w}$ ten sposób materiału [Kroczek 2015, 46-47].

Pomimo, iż przygotowanie przedprocesowe powinno być zorganizowane przez nowe struktury Kościoła, tj. duszpasterstwa małżeństw, to jak uważa T. Rozkrut, może zostać na zasadzie pewnej równoległości przeprowadzone przez adwokata kościelnego i zostać zakończone dobrze sporządzoną skargą powodową, jeśli pozwalają na to okoliczności sprawy. Jest to szczególnie pożądane zwłaszcza tam, gdzie konkretne postanowienia dokumentu papieskiego nie są realizowane [Rozkrut 2018, 149].

\section{ZAKOŃCZENIE DOCHODZENIA PRZEDPROCESOWEGO}

Ustawodawca nie określa czasu, w jakim badanie przedprocesowe powinno się zakończyć. W sytuacji, w której badanie to wykaże istnienie przesłanek, które umożliwiają rozpoczęcie procesu o stwierdzenie nieważności małżeństwa, należy przygotować skargę powodową i złożyć ją we właściwym trybunale (art. 5 Ratio) [Kroczek 2015, 49]. Natomiast należy również pamiętać o kan. $1505 \S 2,4^{\circ} \mathrm{KPK} / 83$ oraz art. $121 \S 1,4^{\circ} \mathrm{DC}$, które dotyczą odrzucenia skargi powodowej, jeśli roszczenie pozbawione jest podstawy i nie ma możliwości, aby w trakcie procesu taka podstawa się ujawniła. Zachować trzeba również art. 120 § 2 DC, który odnosi się do zadania przewodniczącego trybunału przeprowadzenia dochodzenia uprzedniego co do istoty sprawy, gdy w skardze powodowej brak takich podstaw. Czynności tej zaś nie można utożsamiać z dochodzeniem przedprocesowym, o którym mowa w MIDI [Góralski 2017, 53].

Ponieważ przygotowanie przedprocesowe wymaga znajomości prawa kanonicznego, a szczególnie prawa małżeńskiego oraz praktycznego doświadczenia sądowego, stąd też Kongregacja Wychowania Katolickiego w jednej z instrukcji dotyczącej studiów prawa kanonicznego w świetle reformy procesu małżeńskiego ${ }^{10}$, wskazuje na adwokatów i adwokatów stałych,

${ }^{10}$ Kongregacja Edukacji Katolickiej (Instytucji Studiów Wyższych), Instrukcja Studia prawa kanonicznego $w$ świetle reformy procesu małżeńskiego (29.04.2018), http://www.vatican.va/roman_curia/congregations/ccatheduc/documents/rc_con_ccathe duc_doc_20180428_istruzione-diritto-canonico_pl.html [dostęp: 28.10.2019]. 
jako na osoby bezpośrednio i pośrednio zaangażowane w sprawy sądownictwa kościelnego wymagając przy tym od nich stopnia akademickiego. Ponadto podkreśla się, aby chociaż w fazie końcowej badania uczestniczył rzeczywisty ekspert w kanonicznym prawie małżeńskim, który będzie mógł określić istnienie powodów nieważności małżeństwa. $\mathrm{Z}$ pewnością jest to zadanie właściwe dla biegłego adwokata, należycie wykształconego mającego przy tym odpowiednie doświadczenie, aby nie sugerować zainteresowanym prowadzeniem procesu, który od początku byłby skazany na niepowodzenie [Rozkrut 2018, 150-51]. Zanim struktury jednolitego duszpasterstwa zostaną ukonstytuowane, to konieczność wypełnienia zadania zebrania informacji spocznie właśnie na adwokatach [Sztychmiler 2015, 136-37].

W przywołanym wyżej dokumencie Stolicy Apostolskiej zawarto normę, według której doradcy pełniący różne zadania w procesach dotyczących deklaracji nieważności małżeństwa mogą być w sposób użyteczny podzieleni na trzy kategorie: 1) doradcy pierwszego poziomu - proboszczowie i inni posiadający kompetencje nawet niekoniecznie prawno-kanoniczne (art. 3 Ratio, zd. 1). Należy przez to rozumieć tych doradców, którzy mają wystarczającą okazję do pierwszego kontaktu z osobami potencjalnie zainteresowanymi do zweryfikowania nieważności swojego małżeństwa; 2) doradcy drugiego poziomu - członkowie struktury stałej (art. 3 Ratio, zd. 2), tj. duchowni, osoby konsekrowane lub świeccy, zajmujący się poradnictwem rodzinnym. Na tym poziomie konsultacje również mają na celu określenie, czy rzeczywiście wyłaniają się motywy oraz dowody wystarczające dla przedstawienia sprawy o nieważność, aby nie rozpoczynać w sposób nieuzasadniony procesu; 3) doradcy trzeciego poziomu - adwokaci (art. 4 Ratio), w ostatniej fazie konsultacji, która może zakończyć się pozytywnie (wniesieniem skargi powodowej), w której adwokat pomaga w określeniu istotnych elementów oraz dowodowo korzystnych, jak również w zebraniu dowodów już dostępnych, wysłuchaniu opinii drugiej strony, a także w przygotowaniu wszystkiego celem przedstawienia sprawy [Rozkrut 2018, 151].

Wskazując konkretne zadania adwokata kościelnego na etapie dochodzenia przedprocesowego, po pierwsze należy dokładna analiza zebranych elementów, a po drugie, jak najlepsze przygotowanie skargi powodowej (zarówno pod względem formalnym, jak i merytorycznym). W jej wyniku wierni powinni mieć jasną świadomość natury oraz etapów procesu 
małżeńskiego zarówno $\mathrm{w}$ aspekcie formalnym, jak i materialnym [Tenże, 152-53].

\section{ZAKOŃCZENIE}

Podsumowując dotychczasowe rozważania należy stwierdzić, iż właściwe przeprowadzenie dochodzenia przedprocesowego ma niewątpliwie duże znaczenie na przebieg procesu o nieważność małżeństwa. Przede wszystkim już na tym etapie można rozstrzygnąć, czy istnieją jakiekolwiek podstawy do rozpoczęcia procesu, co przekłada się także na koszty sądowe. Jeśli okaże się, że w danej sprawie nie ma uzasadnionych okoliczności, to zainteresowane strony nie poniosą żadnych kosztów, ponieważ skarga powodowa nie zostanie sporządzona i wniesiona. Natomiast w przypadku pozytywnego zakończenia badania przedprocesowego, zostanie nie tylko sporządzona skarga, ale również zostanie zebrana część materiału dowodowego. W ten sposób właściwe merytoryczne przygotowanie małżonków do procesu pozwoli im nie tylko lepiej zrozumieć jego przebieg i znaczenie, ale także pozwoli na jego sprawniejszy przebieg. Poza tym instytucja konsultacji przedprocesowej ma służyć nie tylko małżonkom, którzy są przekonani o nieważności swojego małżeństwa, ale również tym, którzy przeżywają kryzys lub inne trudności. Instytucja ta ma być realizacją założeń całej reformy, a więc ma być skierowana przede wszystkim do tych wiernych, którzy odwrócili się od struktur prawnych Kościoła ze względu na fizyczne lub moralne oddalenie, zaś Kościół pragnie stać się im znowu bliski.

\section{PIŚMIENNICTWO}

Adamowicz, Leszek. 2015. „Okoliczności osób i rzeczy zezwalające na prowadzenie procesu skróconego.” W Proces małżeński według motu proprio Mitis Iudex Dominus Iesus, red. Jan Krajczyński, 93-108. Płock: Płocki Instytut Wydawniczy.

Góralski, Wojciech, 2015. „Wprowadzenie do motu proprio «Mitis Iudex Dominus Iesus»." W Proces małżeński według motu proprio Mitis Iudex Dominus Iesus, red. Jan Krajczyński, 7-21. Płock: Płocki Instytut Wydawniczy.

Góralski, Wojciech. 2017. Proces małżeński skrócony przed biskupem. Płock: Płocki Instytut Wydawniczy.

Kroczek, Piotr. 2015. „Art. 1-6 Ratio.” W Praktyczny komentarz do Listu apostolskiego motu proprio Mitis Iudex Dominus Iesus papieża Franciszka, red. Piotr Skonieczny, 41-54. Tarnów: Wydawnictwo Diecezji Tarnowskiej Biblos. 
Rozkrut, Tomasz. 2018. „Rola adwokata w zreformowanym procesie małżeńskim.” Biuletyn Stowarzyszenia Kanonistów Polskich 31:143-61.

Sztychmiler, Ryszard. 2015. „Posługa adwokata po «Mitis Iudex».” W Proces małżeński według motu proprio Mitis Iudex Dominus Iesus, red. Jan Krajczyński, 127-42. Płock: Płocki Instytut Wydawniczy.

Wenz, Wiesław. 2016. Proces o nieważność małżeństwa według motu proprio «Mitis Iudex Dominus Iesus» Papieża Franciszka w tradycji kanonicznej. Wrocław: Papieski Wydział Teologiczny.

\section{Wpływ dochodzenia przedprocesowego na przebieg procesu o stwierdzenie nieważności małżeństwa}

Streszczenie

W motu proprio Mitis Iudex Dominus Iesus została uregulowana instytucja dochodzenia przedprocesowego. Mimo, iż instytucja ta była znana już w instrukcji procesowej Dignitas connubii, to wymagała dokładniejszego uregulowania. Jej celem jest pomoc małżonkom w poznaniu prawdy o ich małżeństwie. Zagadnienie konsultacji przedprocesowej jest ważne, ponieważ jego właściwe przeprowadzenie będzie miało znaczenie dla ewentualnego rozpoczęcia procesu o stwierdzenie nieważności małżeństwa. Ustanowienie instytucji badania przedprocesowego jest przede wszystkim wyrazem troski o małżonków, którzy żyją w separacji lub rozwiedli się i mają wątpliwość co do ważności sakramentalnego małżeństwa.

Słowa kluczowe: dochodzenie przedprocesowe; proces małżeński; proces o nieważność małżeństwa; reforma procesowa; proces kościelny

\section{Influence the Pre-Judicial Inquiry in the Process on the Nullity of Marriage}

\section{Summary}

The briefer process is a new legal institution in canon law. It was introduced by a motu proprio Mitis Iudex Dominus Iesus as a prejudicial question. This was also described in Dignitas connubii. This will allow for wider dissemination of information concerning there provisions of spouses in their matrimony. The issue of pre-trial tutorship it is very important in the briefer process of the nullity of marriage.

Key words: pre-judicial inquiry; matrimonial process; process on the nullity of marriage; the process reform; ecclesiastical process

Information about Author: MonIKA GÓRNA, J.C.L. - Ph.D. student, Department of Church Procedural Law, Marriage Law and Penal Law and the Eastern Catholic Churches, Institute of Canon Law, Faculty od Law, Canon Law and Administration at the John Paul II Catholic University of Lublin; Al. Racławickie 14, 20-950 Lublin, Poland; e-mail: monikagorna94@gmail.com; https://orcid.org/0000-0002-8494-4417 